\title{
NEUROTROPHINS, THEIR RECEPTORS AND KI-67 IN HUMAN GH-SECRETING PITUITARY ADENOMAS: AN IMMUNOHISTOCHEMICAL ANALYSIS
}

\author{
M. ARTICO ${ }^{1}$, E. BIANCHI ${ }^{1}$, G. MAGLIULO ${ }^{1}$, M. DE VINCENTIIS ${ }^{1}$, E. DE SANTIS ${ }^{2}$, A. \\ $\mathrm{ORLANDI}^{3}$, A. SANTORO ${ }^{4}$, F.S. PASTORE ${ }^{5}$, F. GIANGASPERO ${ }^{6}, \mathrm{R}$. CARUSO ${ }^{4}$, \\ M. RE$^{7}$ and L. FUMAGALLI ${ }^{2}$
}

\begin{abstract}
${ }^{1}$ Department of Sensory Organs, University of Rome "Sapienza”, ${ }^{2}$ Department of Anatomical Histological, Forensic and Locomotor system Sciences, University of Rome "Sapienza”, Rome, Italy; ${ }^{3}$ Chair of Pathology, University of Rome "Tor Vergata", Italy; ${ }^{4}$ Department of Neurological Sciences, Neurosurgery, University of Rome "Sapienza”, Rome, Italy; ${ }^{5}$ Division of Neurosurgery, University of Rome "Tor Vergata”, Rome, Italy; 'Department of Radiology, Oncology and Anatomic Pathology, University of Rome "Sapienza” \& IRCCS Neuromed, Pozzilli (Is), Italy; " Department of Clinical Sciences, Polytechnic University of Marche, Ancona, Italy

\section{Received June 1, 2011 - Accepted January 13, 2012}

Pituitary adenomas are a diverse group of tumors arising from the pituitary gland. Typically, they are small, slow-growing, hormonally inactive lesions that come to light as incidental findings on radiologic or postmortem examinations, although some small, slow-growing lesions with excessive hormonal activity may manifest with a clinical syndrome. The family of neurotrophins plays a key role in the development and maintenance of the pituitary endocrine cell function and in the regulation of hypothalamo-pituitaryadrenocortical axis activity. The objective of our experimental study is to investigate the localization of the neurotrophins, their relative receptors and to detect the expression level of Ki-67 to determine whether all these factors participate in the transformation and development of human pituitary adenomas. A very strong expression of Neurotrophin-3 (NT-3) and its receptor TrKC was observed in the extracellular matrix (ECM) and vessel endothelium, together with a clear/marked presence of Brain-derived neurotrophic factor (BDNF), and its receptor TrKB, thus confirming their direct involvement in the progression of pituitary adenomas. On the contrary, NGF (Nerve growth factor) and its receptor TrKA and p75NTR were weakly expressed in the epithelial gland cells and the ECM.

Pituitary adenomas are a diverse group of tumors arising from the pituitary gland $(1,2)$ which can be sub-classified as either functional or non-functional, depending on their hormonal activity in vivo (2-4). Small, slow-growing, hormonally-inactive lesions are typically identified as incidental findings on radiologic or post-mortem examinations: other small, slow-growing lesions with excessive hormonal activity can manifest with a clinical syndrome (2-4). Tumors that grow more rapidly, even if hormonally inactive, are capable of producing symptoms related to the presence of an intracranial mass, such as visual

Key words: pituitary gland, adenoma, neurotrophins, Ki-67, immunohistochemistry

Mailing address: Prof. Marco Artico, M.D., Pharm. D.,

Department of Sensory Organs, 
field disturbances. Given the small size of many pituitary tumors and their propensity to exist with only insidious, non-specific symptoms, an accurate estimate of the incidence of pituitary adenomas in the general population appears challenging (4). Ezzat et al. found prolactinomas to be the most common form of pituitary adenoma (1). Burrow and co-workers (5) evaluated postmortem radiographic, macroscopic and microscopic findings in the pituitary tumors and found a significant incidence $(11 \%)$ of prolactinoma in both men and women at all ages, despite the fact that the etiologies of most pituitary tumors remain unknown, as confirmed by more recent experimental findings $(6,7)$. The family of neurotrophins plays a key role in the development and maintenance of nerve cell populations in the peripheral and central nervous system (8-12). Several lines of evidence suggest that neurotrophins, more particularly NGF, may be involved in pituitary endocrine cell function (13, 14). Animal studies have shown that neurotrophins, especially NGF, play a dual role in pituitary physiology. Firstly, a local role, in the anterior pituitary gland, as a stimulator of differentiation and proliferation of somatomammotroph cells into mammotroph or lactotrope cells during development (15-18) as well as a stimulator of proliferation of the thyrotrope cells (18). Secondly, a systemic role as a neurohormone which is co-secreted with prolactin into the bloodstream (16). Furthermore, NGF may regulate endocrine function by stimulating the hypothalamo-pituitary-adrenocortical axis activity during stress responses, pregnancy and lactation (19). In vitro studies revealed that escape from NGF control appears to be one of the mechanisms involved in the development and progression of human prolactinomas (20). NGF and Trk receptors have been identified in endocrine cells (cells containing conventional anterior - pituitary hormones) in the anterior pituitary gland of adult rats $(14,17,18)$, and Aguado et al. (14) reported the presence of numerous endocrine cells containing TrkA and TrkB receptors in human anterior pituitary gland and some pituitary adenomas, suggesting a direct role of the neurotrophins in the normal development of the pituitary gland and in the progression of some pituitary adenomas. Previous observations found that prolactinomas, the most common pituitary tumor, express NGF and its receptors (TrkA and TrkB) and are therefore highly sensitive to the action of that neurotrophic factor. In fact, NGF mediates a long-lasting conversion of the more transformed dopamine-resistant prolactinomas into a differentiated, less malignant lactotroph- like phenotype re-expressing the D-2 receptor protein: the latter is very important in the pharmacological therapy of these tumors because D-2 receptor agonists are strongly effective in lowering plasma prolactin (PRL) levels in patients with prolactinomas (21). It has also been suggested that BDNF, expressed together with its receptor TrkB in the anterior lobe of the pituitary gland, is involved in the control of thyroid function, in the proliferation and differentiation of melanotrope cells and in the regulation of the hypothalamic-pituitaryadrenal axis $(22,23)$. All these findings prompted us to investigate the localization and intra-cellular distribution of the neurotrophins and their relative receptors, to determine whether these growth factors participate in the transformation and development of the human pituitary adenomas.

Although most pituitary microadenomas can be completely excised, it is difficult to totally remove invasive pituitary macroadenomas and, to date, no routine markers have been available to predict the aggressive behavior or recurrence of this lesion. However, Ki-67, a nuclear antigen recognized by the monoclonal antibody MIB-1 has proved to be useful in assessing several brain tumors, providing information about cell proliferation and, consequently, long-term prognosis $(24,28)$. Generally, the Ki-67 labeling index (LI) in pituitary adenomas is relatively low in comparison to other brain tumors (29-31) in which it is employed, together with a thorough clinical, hormonal and MR image follow-up, to identify the predicted recurrence of the tumor as early as possible. Hence, we decided to investigate, together with the analysis of the neurotrophins pattern, the expression level of Ki-67 to define its possible role as a prognostic factor in pituitary adenomas.

\section{MATERIALS AND METHODS}

\section{Patients}

Small specimens of human GH-secreting pituitary adenomas (invasive macroadenomas) were harvested, during surgical operation through transnasal traditional 
and endoscopic approach, from 10 patients, and then processed for immunohistochemical analysis. Control specimens from normal pituitary gland were obtained from 2 autoptic cases. Experiments were performed in compliance with the Italian laws and guidelines concerning the informed consent of patients (Dir. 2001/20/CE). The following molecules were investigated: nerve growth factor (NGF), brain-derived neurotrophic factor (BDNF), NT-3, NT-4, TrKA, TrKB, TrKC, p75NTR and Ki-67.

\section{Immunohistochemical analysis}

For light microscope immunohistochemical analysis, small fragments of human GH-secreting adenomas were washed in PBS, fixed in 10\% formalin and embedded in paraffin according to a standard procedure. Serial 4 $\mu \mathrm{m}$ thick sections were cut using a rotatory microtome, mounted on gelatine-coated slides and processed for immunohistochemistry. To study the immunolocalization of neurotrophins and their receptors, the antibodies we used were: i) rabbit anti-NGF polyclonal antibody (Santa Cruz Biotechnology, CA, USA), which display $<1 \%$ cross-reactivity against recombinant human NT-3, NT-4 and BDNF; ii) rabbit anti-BDNF polyclonal antibody (Santa Cruz), which recognizes the amino-terminus of mouse BDNF and does not cross-react with NT-3 or NGF; iii) rabbit anti-NT3 polyclonal antibody (Santa Cruz Biotechnology), raised against the amino-terminus of mouse NT-3, which does not cross-react with NGF or BDNF; iv) rabbit anti-NT4 polyclonal antibody (Santa Cruz Biotechnology); v) rabbit anti-TrKA polyclonal antibody (Santa Cruz Biotechnology), which recognizes an epitope corresponding to amino acids 763 to 777, mapping adjacent to the carboxy-terminus of human TrKA p140 and is not cross-reactive with $\operatorname{TrKB}$ or $\operatorname{TrKC}$; vi) rabbit antiTrKB polyclonal antibody (Santa Cruz Biotechnology), which recognizes an epitope corresponding to amino acids 794 to 808 of mouse TrKB p145 and is not crossreactive with $\operatorname{TrKA}$ or $\operatorname{TrKC}$; and vii) rabbit anti-TrKC polyclonal antibody (Santa Cruz Biotechnology), which recognizes an epitope corresponding to amino acids 798 to 812 of porcine TrKC p140 and is not cross-reactive with TrKA or TrKB; viii) goat polyclonal antibody to human NGF receptor p75 (Santa Cruz Biotechnology), which recognizes the amino acid sequence mapping the carboxy-terminus of the NGF receptor p75 precursor of human origin and is not cross-reactive with other growth factor receptors; viiii) MIB-1, a rabbit polyclonal antibody raised against amino acids 2641-2940 mapping at the Cterminus of $\mathrm{Ki}-67$ of human origin (Santa Cruz, CA, USA). Incubation with primary antibodies was performed overnight at $4^{\circ} \mathrm{C}$ at a final concentration of $2-5 \mu \mathrm{g} / \mathrm{ml}$. Optimal antisera dilutions and incubation times were assessed in a series of preliminary experiments. After exposure to the primary antibodies, slides were rinsed twice in phosphate-buffer and incubated $(1 \mathrm{~h}$ and $30 \mathrm{~min}$ at room temperature) with the appropriate secondary antibody conjugated to horseradish peroxidase (HRP) (final dilution 1:100). The secondary antibody-HRP linked against rabbit immunoglobulins was purchased from Boehringer (Boehringer Mannheim $\mathrm{GmbH}$, Mannheim, Germany), while secondary antibodies-HRP linked against mouse and goat immunoglobulins were from Sigma (Sigma Chemicals Co, St. Louis, MO, USA). After a further wash with phosphate buffer, slides were treated with $0.05 \%$ 3,3-diaminobenzidine and $0.1 \%$ $\mathrm{H}_{2} \mathrm{O}_{2}$. Finally, sections were counterstained with Mayer's hematoxylin and observed by using a light microscope. To block endogenous peroxidase activity, slides were pretreated with $3 \% \mathrm{H}_{2} \mathrm{O}_{2}$, whereas the non-specific binding of immunoglobulins was prevented by adding $3 \%$ fetal calf serum to the incubation medium. The intensity of the immune reaction was assessed microdensitometrically using an IAS 2000 image analyzer (Delta Sistemi, Rome, Italy) connected via a TV camera to the microscope. The system was calibrated taking as zero the background obtained in sections exposed to nonimmune serum. Ten $100 \mu \mathrm{m}_{2}$ areas were delineated in each section by a measuring diaphragm. Quantitative data regarding the intensity of the immune staining were analyzed statistically by analysis of variance (ANOVA) followed by Duncan's multiple range test as a post hoc test.

\section{RESULTS}

\section{Immunohistochemistry}

Sections of GH-secreting adenoma samples exposed to the primary/secondary antibodies developed a dark-brown (intense), yellow-brown (slight) or no appreciable immunostaining. Immunoreactivity was specific since no immunostaining was obtained in positive control sections incubated with each primary antibody adsorbed with the specific peptide or with preimmune serum (data not shown). Immunolabeling was located in the epithelial glands (described as epithelial neoplastic cells), extracellular matrix (ECM) and vessel endothelium (Tables I and II). Immunoreaction for NGF was moderate on epithelial glands (ep) and also appeared weak in the ECM (em), but was totally absent on the endothelium of the vessels (en) (Fig. 1A). Similarly TrkA immunoreactivity was moderate on epithelial glands (ep) and less appreciable in the ECM (em), but absent on the vessel endothelium (en) (Fig. 1B). A weak 
Table I. Results of the immunohistochemical analysis for NTs and NT receptors in human GH-secreting pituitary adenomas.

\begin{tabular}{|c|c|c|c|}
\hline & $\begin{array}{c}\text { Epithelial } \\
\text { glands }\end{array}$ & $\begin{array}{c}\text { Extracellular } \\
\text { matrix }\end{array}$ & $\begin{array}{c}\text { Vessel } \\
\text { endothelium }\end{array}$ \\
\hline NGF & + & $+/-$ & - \\
\hline BDNF & ++ & +++ & + \\
\hline NT3 & + & +++ & ++ \\
\hline MIB -1 & $+/-$ & ++ & - \\
\hline TrkA & + & $+/-$ & + \\
\hline TrkB & $+/-$ & ++ & ++ \\
\hline TrkC & $+/-$ & +++ & - \\
\hline p75NTR & $+/-$ & $+/-$ & \\
\hline
\end{tabular}

+++: strong immunoreactivity; ++: relevant immunoreactivity; +: moderate immunoreactivity; +/-: weak immunoreactivity; -: absence of immunoreactivity

Table II. Results of the immunohistochemical analysis in percentages.

\begin{tabular}{|c|c|c|c|}
\hline & $\begin{array}{c}\text { Epithelial } \\
\text { glands }\end{array}$ & $\begin{array}{c}\text { Extracellular } \\
\text { matrix }\end{array}$ & $\begin{array}{c}\text { Vessel } \\
\text { endothelium }\end{array}$ \\
\hline NGF & $\pm 50 \%$ & $\pm 25 \%$ & $\pm 0 \%$ \\
\hline BDNF & $\pm 75 \%$ & $\pm 100 \%$ & $\pm 50 \%$ \\
\hline NT3 & $\pm 50 \%$ & $\pm 100 \%$ & $\pm 75 \%$ \\
\hline MIB - 1 & $\pm 25 \%$ & $\pm 75 \%$ & $\pm 0 \%$ \\
\hline TrkA & $\pm 50 \%$ & $\pm 25 \%$ & $\pm 0 \%$ \\
\hline TrkB & $\pm 25 \%$ & $\pm 75 \%$ & $\pm 50 \%$ \\
\hline TrkC & $\pm 25 \%$ & $\pm 100 \%$ & $\pm 75 \%$ \\
\hline p75NTR & $\pm 25 \%$ & $\pm 25 \%$ & $\pm 0 \%$ \\
\hline
\end{tabular}



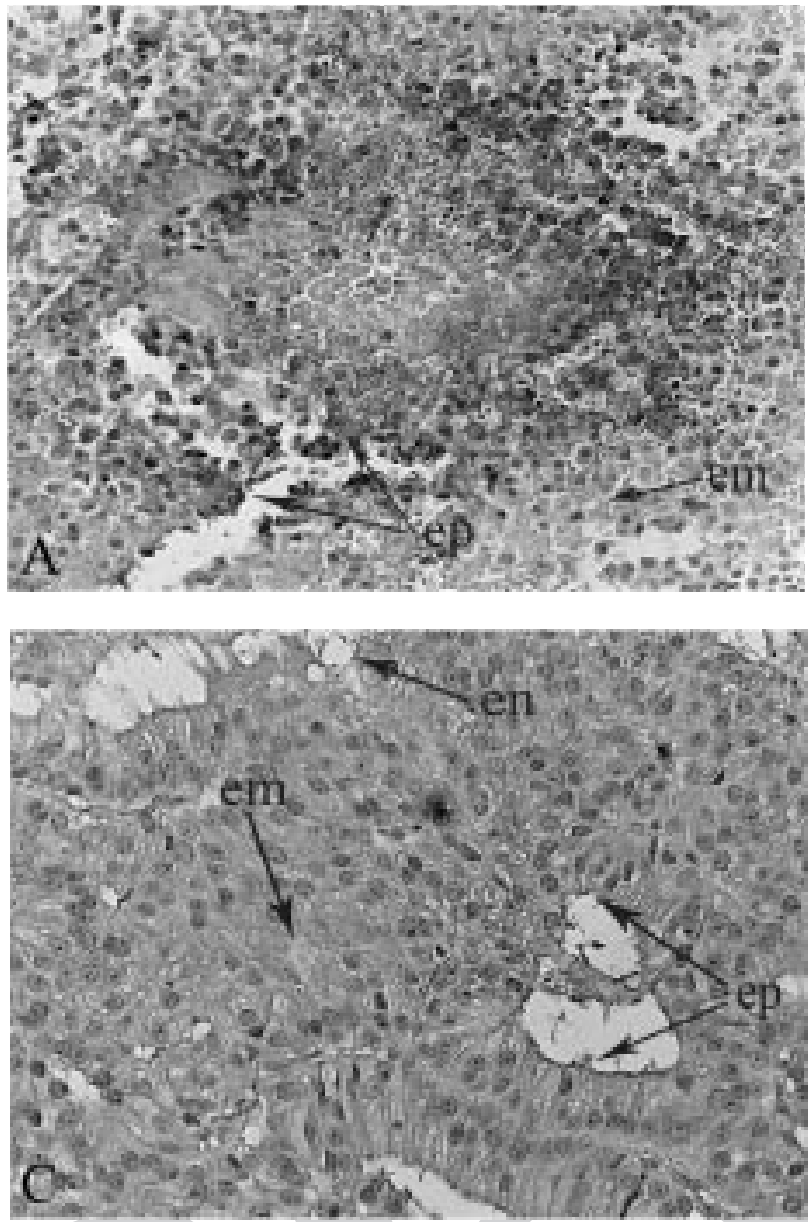

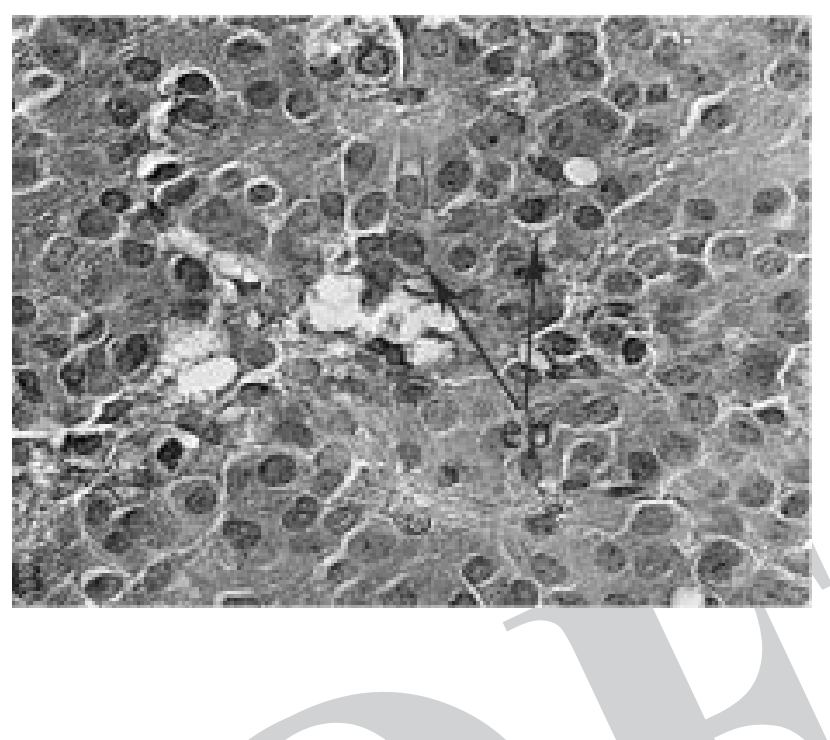

Fig. 1. Micrographs of NGF-TrKA-P75 immunostaining in $G H$-secreting pituitary adenomas. NGF immunoreactivity was moderate in the epithelial compartment of the neoplastic area, weak in the extracellular matrix (em) and totally absent in the vessel endothelium (en) (not shown) (A: 20X). Immunoreaction for TrKA was moderate in the nucleus of the neoplastic cells, weak in the extracellular matrix (not shown) and totally absent in the vessel endothelium (en) (not shown) (B: 40X). P75NTR immunoreactivity was weak in the epithelial neoplastic cells and in the extracellular matrix (em), but totally absent in the vessel endothelium (en) (C: 20X).
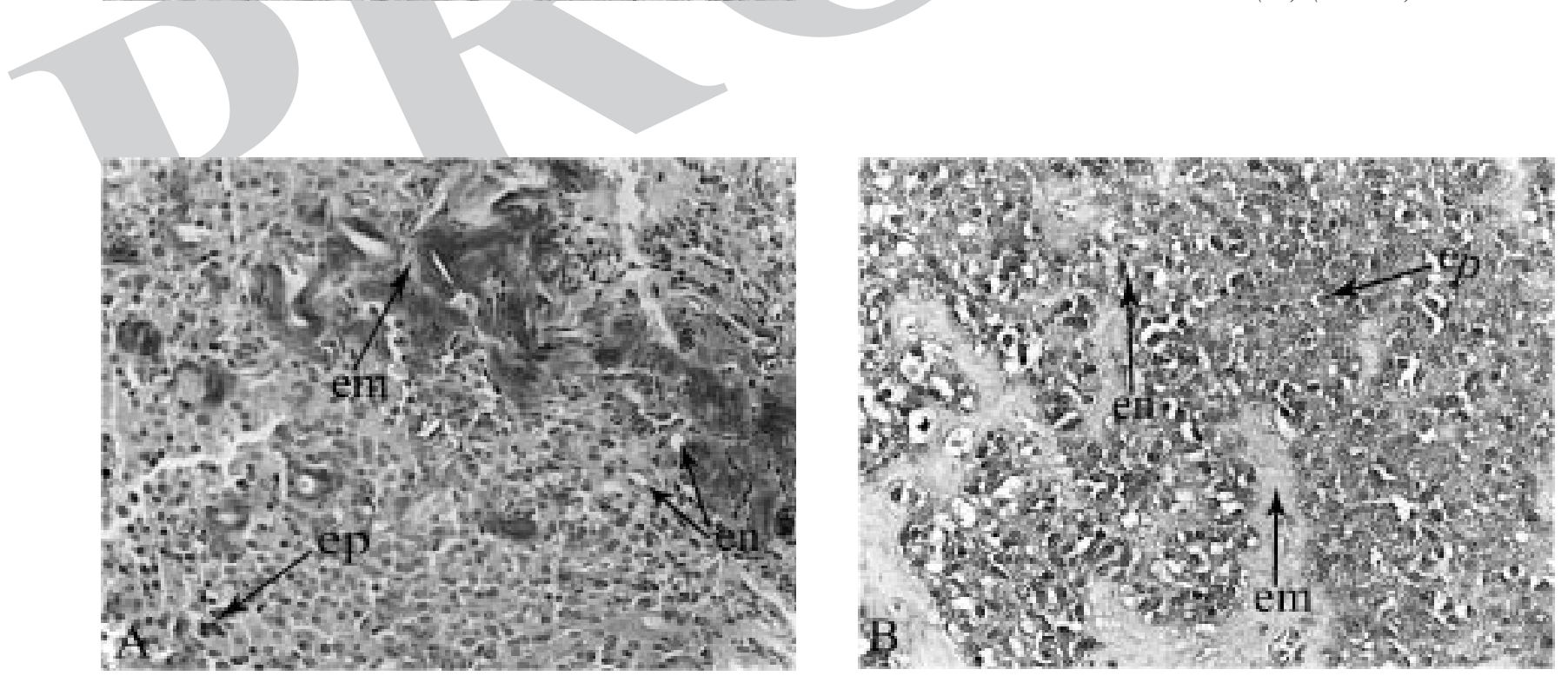

Fig. 2. Micrographs of BDNF-TrKB immunostaining in GH-secreting pituitary adenomas. BDNF showed a significantly high expression in the extracellular matrix (em) and on epithelial glands, but moderate on the vessel endothelium (en) (A: 20X). TrKB Immunoreactivity was strong in the extracellular matrix (em), appreciable in the vessel endothelium (en) and weak on epithelial glands of the neoplastic area (B: 20X). 

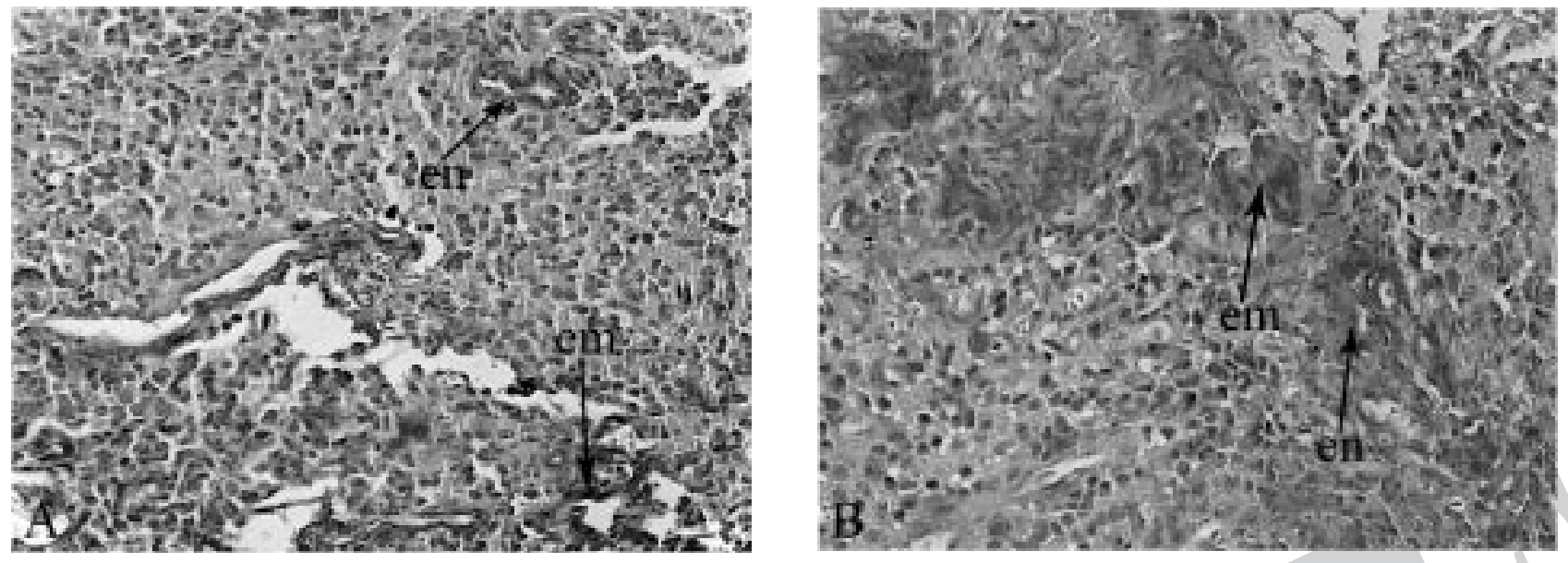

Fig. 3. Micrographs of NT3-TrKC immunostaining in GH-secreting pituitary adenomas. NT-3 was strongly expressed in the extracellular matrix (em) and on the vessel endothelium (en), but it was moderate expressed in the epithelial neoplastic cells. (A: 20X). A strong immunoreactivity for TrKC was observed in the extracellular matrix (em) and a weak expression on the vessel endothelium (en) and on epithelial glands (ep) (B: 20X).
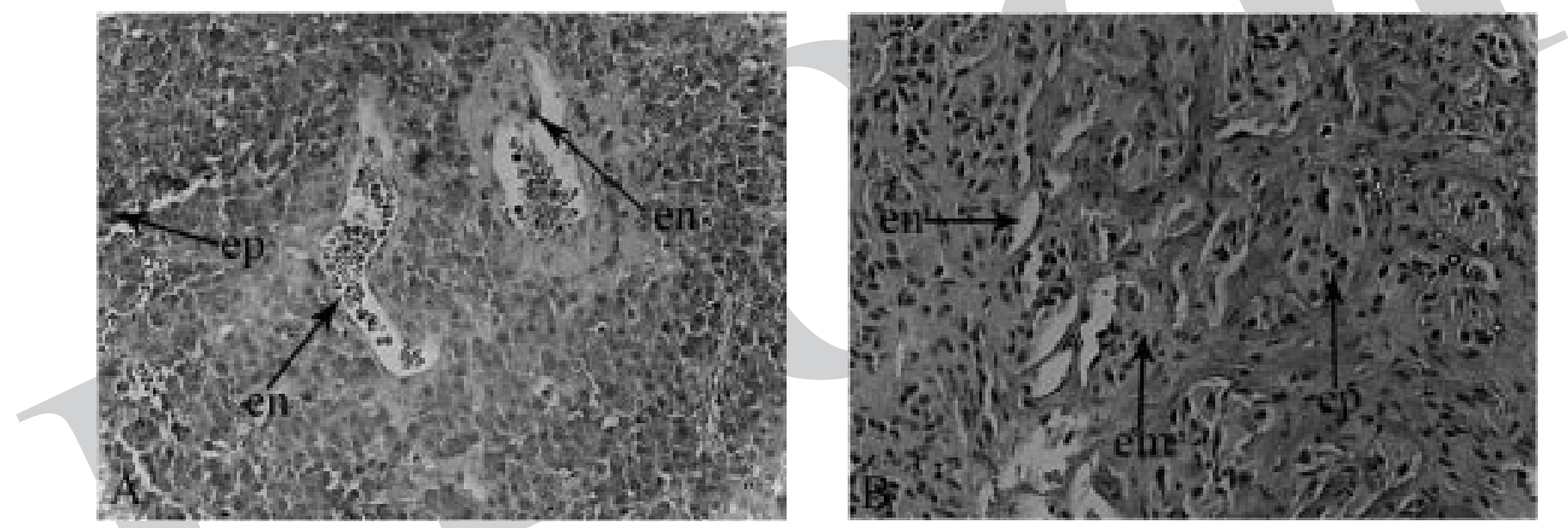

Fig. 4. Micrographs of Ki-67 immunostaining in GH-secreting pituitary adenomas. Ki-67 immunoreactivity was weak on epithelial neoplastic cells and on the vessel endothelium (en), but it was relevant in the extracellular matrix (em) (A, B: 20X)

immunoreactivity for the p75NTR was described on epithelial glands (ep) and in the ECM (em), while it was absent on the endothelium of vessels (en) (Fig. 1C). BDNF immunoreactivity was highly appreciable in the ECM (em) and on epithelial glands (ep), but it resulted moderate on the vessel endothelium (en) (Fig. 2A). A strong immunoreactivity for TrKB was observed in the ECM (em), appreciable in the vessel endothelium (en) and weak on epithelial glands (ep) of the neoplastic area (Fig. 2B). A very strong immunoreactivity was revealed by NT-3 and TrKC in the ECM (em), an appreciable expression also on the vessel endothelium (en) and a weak immunoreactivity on epithelial glands (ep) for these factors (Fig. 3 A, B). Finally Ki-67 immunoreactivity was weakly expressed on epithelial glands (ep) and on the vessel endothelium (en) (Fig. 4 A, B). Results are summarized in Tables I and II. Illustrations regarding autoptic findings (2 cases) are not provided because immunoreactivity was absent or not significant.

\section{DISCUSSION}

Pituitary adenomas account for $10-15 \%$ of all primary brain tumors and benign tumors and are 
usually slow-growing (1-4). In particular, growth hormone-secreting adenomas account for about $20 \%$ of all pituitary adenomas. GH-producing adenomas are hormone-secreting invasive macroadenomas and have been histologically classified into densely and sparsely granulated adenomas (32). They derive from the acidophil cell line. This lineage, comprising somatotroph, mammotroph and thyrotroph cells, is controlled by a common transcription factor named PIT-1 (Pituitary-specific positive transcription factor 1). Previous studies suggest that neurotrophins, especially NGF, may be involved in pituitary endocrine cell proliferation, growth and differentiation $(13,14)$. NGF is a particularly interesting neurotrophin in pituitary function and physiology (1-18).

Immunohistochemical studies have also shown that NGF is selectively expressed by somatotroph, mammotroph and thyrotroph cells, stored in secretory granules. Moreover, neurotrophins and their receptors have been shown to play a role in cancer, promoting tumor progression. In particular, NGF cooperates with EGF (epidermal growth factor) and bFGF (basic fibroblast growth factor) in directing differentiation of lactotroph cells stimulating PRL synthesis and D-2 dopaminergic receptor expression (21), via binding to p75NTR and activation of NF-kB (nuclear factor-KB) in a TrkA-independent way. In fact, short-term treatment of patients with bromocriptine-resistant prolactinomas, with NGF resulted in differentiation of the tumors into less aggressive, lactotrope-like cells, re-expressing D-2 receptors, thus restoring the molecular target for conventional therapy with D-2 agonists (21). TrkA as well as TrkB expression has been found in tumoral and non-tumoral adenohypophyseal cells from human pituitary adenomas by Aguado et al. (14). However, the localization of the neurotrophin receptors in normal human pituitary gland and their expression in human pituitary adenomas is still unclear. In our observations we described a moderate immunoreaction for NGF, and its relative receptor TrKA and p75NTR, on epithelial glands and less appreciable in the ECM, similar to the experimental observations made by Assimakopoulou et al. (13) but different from those of Aguado's et al. (14): this suggests a role of NGF and its signaling in the development of normal pituitary gland but not in the progression and proliferation of the pituitary adenomas. BDNF and its receptor TrKB resulted highly appreciable in the ECM and moderate on the vessel endothelium, suggesting their participation in the proliferation of a neoplastic microenvironment, involving the extracellular matrix components and the angiogenetic network, owing to the fact that vascular endothelial cells synthesize and secrete BDNF (32). The new experimental evidence of our results is, in fact, demonstrated by the prominent immunoreactivity of BDNF and $\operatorname{TrKB}$ in the neoplastic tissue. The latter result is not found in normal pituitary specimens. On the other hand, a very strong immunoreactivity was revealed by NT-3 and $\mathrm{TrKC}$ in the ECM, and an appreciable expression also on the vessel endothelium, contrary to Aguado's findings (14), leading us to describe this neurotrophin as the principal neurotrophic factor involved in the progression of pituitary adenomas. This discrepancy may be due to the different immunohistochemical experimental protocols employed. Considering the efficiency of the antibodies used for this investigation, the expression revealed by these molecules in human pituitary adenomas (GHsecreting) suggests a direct functional role of BDNF and NT-3 on these tumors. Finally Ki-67 resulted weakly detectable in epithelial glands, but totally absent on the vessel endothelium, confirming the low proliferation rate of $\mathrm{GH}$-producing adenomas which generally show a label index less than $3 \%$. However, the distribution and localization of all these factors in human pituitary adenomas $(\mathrm{GH}-$ secreting) still remains unclear. Additional studies appear necessary to better explain the biological role of these molecules in the development and progression of this type of tumor.

\section{REFERENCES}

1. Ezzat S, Asa SL, Couldwell WT, Barr CE, Dodge WE, Vance ML, McCutcheon IE. The prevalence of pituitary adenomas: a systematic review. Cancer 2004; 101(3):613-9.

2. Asa SL. Tumors of the pituitary gland. In: Rosai J, editor. Atlas of tumor pathology. $3^{\text {rd }}$ series Fascicle 22. Washington DC: Armed Forces Institute of Pathology, 1998; 1-214. 
3. Asa SL, Ezzat S. The pathogenesis of pituitary tumors. Nat Rev Cancer 2002; 2:836-49.

4. Nammour GM, Ybarra J, Naheedy MH, Romeo JH, Aron DC. Incidental pituitary macroadenoma: a population-based study. Am J Med Sci 1997; 314: 287-91.

5. Burrow GN, Wortzman G, Rewcastle NB, et al. Microadenomas of the pituitary and abnormal sellar tomograms in an unselected autopsy series. N Engl J Med 1981; 304:156-8.

6. Ezzat S. Editorial: Pituitary tumor pathogenesis - The hunt for novel candidate genes continues. J Clin Endocr Metabol 2003; 88(11):5116-8.

7. Asa SL, Ezzat S. The pathogenesis of pituitary tumors. Annual Review of Pathology: Mechanisms of Disease 2009; 4:97-126.

8. Lewin GR, Bardle YA. Physiology of neurotrophins. Ann Rev Neurosci 1996; 9:217-89.

9. Barbacid M. The TrK family of neurotrophin receptors. J Neuroimmunol 1994; 25:1386-403.

10. Kaplan DR, Miller FD. Signal transduction by the neurotrophin receptors. Curr Opin Cell Biol 1997; 9: 213-21.

11. Snider WD. Functions of the neurotrophins during nervous system development: what the knockouts are teaching us. Cell 1994; 77:627-38.

12. Tessarollo L. Pleiotropic functions of neurotrophins in development. Cytokine Growth Factor Rev 1998; 9:125-37.

13. Assimakopoulou M, Vassiliki Z, Chondrogianni C, Gatzouins G, Varakis J. p75NTR and TrkC Neurotrophin receptors demonstrate a different immunoreactivity profile in comparison to TrkA and TrkB receptors in human normal pituitary gland and adenomas. Neuroendocrinology 2008; 88:127-34.

14. Aguado F, Majò G, Aranda G, Ferrer I. Trk neurotrophin receptor family immunoreactivity in rat and human pituitary tissues. Neuroscience Letters 1998; 243:13-16.

15. Missale C, Boroni F, Sigala S, Zanellato A, Dal Toso R, Balsari A, Spano P. Nerve growth factor directs differentiation of the bipotential cell line GH-3 into the mammotroph phenotype. Endocrinology 1994; 135(1):290-8.

16. Missale C, Boroni F, Sigala S, Buriani A, Fabris M, Leon A, Dal Toso R, Spano F. Nerve growth factor in the anterior pituitary: localization in mammotroph cells and cosecretion with prolactin by a dopamineregulated mechanism. Proc Natl Acad Sci 1996; 93: 4240-5.

17. Patterson J, Childs G. Nerve growth factor and its receptor in the anterior pituitary. Endocrinology 1994; 135(4):1689-96.

18. Patterson J, Childs G. Nerve growth factor in the anterior pituitary: regulation of secretion. Endocrinology 1994; 135(4):1697-704.

19. Taglialatela G, Angelucci L, Scaccianoce S, Foreman PJ, Perez-Polo JR. Nerve growth factor modulates the activation of the hypothalamo-pituitaryadrenocortical axis during the stress response. Endocrinology 1991; 129:2212-18.

20. Missale C, Fiorentini C, Finardi A, Spano PF. Growth factors in human pituitary tumors. Pituitary 1999; 1:153-8.

21. Missale C, Boroni F, Losa M, Giovanelli M, Zanellato A, Dal Toso R, Balsari A and Spano PF. Nerve growth factor suppresses the transforming phenotype of human prolactinomas. Proc Natl Acad Sci USA 1993; 90:7961-5.

22. Kramer B ,Cruijsen P, Ouwens D, Coolen M, Martens G, Roubos E, Jenks B. Evidence that brainderived neurotrophic factor acts as an autocrine factor on pituitary melanotrope cells of Xenopus laevis. Endocrinology 2002; 143(4):1337-45.

23. Kononen J, Soinila S, Persson H, Honkaniemi J, Hokfelt T, Pelto-Huikko M. Neurotrophins and their receptors in the rat pituitary gland: regulation of BDNF and trkB mRNA levels by adrenal hormones. Brain Res Mol Brain Res 1994; 27(2):347-54.

24. Ekramullah SM, Saitoh Y, Arita N, Ohnishi T, Hayakawa T. The correlation of Ki-67 staining indices with tumor doubling times in regrowing non-functioning pituitary adenomas. Acta Neurochir (Wien) 1996; 138:1449-55.

25. McCormick D, Chong H, Hobbs C, Datta C, Hall PA. Detection of the Ki-67 antigen in fixed and waxembedded sections with the monoclonal antibody MIB-1. Histopathology 1993; 22:355-60.

26. Kim SY, Chung SH, Kim HJ, Whang K, Han YP, Hong SK. Bcl-2 and Bax expression and Ki-67 proliferative index in astrocytic tumors: in relation to prognosis. J Korean Neurosurg Soc 2004; 35:465-71. 
27. Parkins CS, Darling JL, Gill SS, Revesz T, Thomas DG. Cell proliferation in serial biopsies through malignant brain tumors: measurement using $\mathrm{Ki}-67$ antibody labeling. Br J Neurosurg 1991; 5:289-98.

28. Kitz K, Knosp E, Koos WT, Korn A. Proliferation of pituitary adenomas. Measurement by MAb Ki-67. Acta Neurochir (Wien) 1991; 53:60-4.

29. Paek KI, Kim SH, Song SH, Choi SW, Koh HS, Youm JY, Kim Y. Clinical significance of Ki-67 labeling index in pituitary macroadenoma. J Korean Med Sci 2005; 20:489-94.

30. Kim JH, Seo JS, Lee BW, Lee SY, Jeon SH, Lee KB. The Characteristics of incidental pituitary microadenomas in 120 korean forensic autopsy cases. J Korean Med Sci 2007; 22:61-5.

31. Nakahashi T, Fujimura H, Altar A, Li J, Kambayashi J-I, Tandon NN, Sun B. Vascular endothelial cells synthesize and secrete brain-derived neurotrophic factor. FEBS Lett 2000; 470:113-7.

32. Kontogeorgos G, Watson Jr RE, Lindell EP. Growth hormone producing adenoma. In: DeLellis RA, Lioyd RV, Heitz PU, Eng C eds. World Health Organization Classification of Tumors: Pathology and Genetics of Tumors of Endocrine Organs. Lyon, France: International Agency for Research on Cancer Press 2004; 14-19. 